\title{
HUBUNGAN KINERJA PERAWAT PROFESIONAL DENGAN PRAKTIK KLINIK KEPERAWATAN MEDIKAL BEDAH MAHASISWA PROFESI NERS DI RSUD JAYAPURA PROPINSI PAPUA
}

\section{(Relationship Between Professional Nurse Performance with Clinical Practice of Nursing Student at Medical Surgical Nursing in Hospital Jayapura Papua Province)}

\author{
John Toding Padang, Novita Medyati \\ Program Studi Ilmu Keperawatan, Fakultas Kedokteran Universitas Cenderawasih \\ Fakultas Kesehatan Masyarakat Universitas Cenderawasih \\ e-mail: john.todingpadang@yahoo.com
}

\begin{abstract}
Clinical practice experience is a kind of learning that must be done in nursing education. Result of job performance of an organization needs measurement standard so the assessment of performance is an essential aspect for hospitals to improve nurse professional performance. Students attendance at nursing clinical practice creates function, role and responsibility in supervisory activities of heads of wards, nurses, and clinical supervisors. Purpose of this study was to assess nurse performance at Jayapura Hospital, Province of Papua in the implementation of medical surgical nursing clinical practice of nursing profession students. Method: Research study was descriptive with cross sectional design. Research sample was 73 consist of 7 heads nurse, 58 nurses, and 8 clinical instructor at inpatient rooms and 49 nursing profession students. Data collected at July $2^{\text {nd }}$ until $16^{\text {th }}, 2014$ by using selfadministered questionaire and proceeded using software. The conclusion is availability of the study average performance of nurses was high. However according to students evaluation average performance of nurses was adequate.
\end{abstract}

Keywords: Nurse performance, clinical learning experience, medical-surgical nursing practice, nursing students

Pendidikan profesi ners merupakan proses pembelajaran yang menekankan pada tumbuh kembangnya kompetensi klinik untuk menjadi seorang perawat profesional. Landasan tumbuh kembangnya kompetensi ini merupakan kerangka konsep pendidikan yang meliputi falsafah keperawatan sebagai profesi dan keperawatan sebagai pelayanan profesional. Untuk memperoleh kompetensi tersebut diperlukan suatu seting pengalaman belajar melalui praktik keperawatan yang memberikan kesempatan kepada mahasiswa profesi ners untuk dapat menerapkan ilmu dan kiat keperawatan secara terintegrasi pada tatanan layanan kesehatan. Karena tatanan layanan kesehatan tersebut merupakan suatu muara yang akan mewujudkan penampilan seorang perawat profesional. Kompetensi keperawatan medikal bedah merupakan salah satu kompetensi klinik dalam kurikulum profesi ners yang sangat dominan dan mutlak harus dicapai di tatanan klinik. Pencapaian tersebut harus melalui pengalaman praktik pembelajaran klinik keperawatan yang terdiri dari beberapa tingkatan yaitu pemaparan, partisipasi, identifikasi, internalisasi, dan diseminasi (Nicklin \& Kenworthy, 2008). Penelitian yang dilakukan oleh Ortom (dalam Billings \& Halstead, 2005), menyatakan bahwa pembelajaran praktik klinik sangat dipengaruhi oleh iklim dan sistim di tatanan klinik. Pada penelitian lain mengenai efektivitas bimbingan, menyatakan bahwa pembimbing klinik sangat berperan penting dalam perkembangan pencapaian pengetahuan, sikap, dan keterampilan psikomotor seorang mahasiswa (Spouse dalam Dorothy, 2002). Keberadaan mahasiswa profesi ners dalam melakukan praktik klinik keperawatan medikal bedah di institusi layanan kesehatan dalam hal ini rumah sakit, menuntut fungsi, peran, dan tanggung 
jawab perawat baik sebagai kepala ruang perawatan, pembimbing klinik maupun sebagai perawat pelaksana untuk melakukan proses bimbingan klinik. Peran dan tanggung jawab kepala ruang perawatan, pembimbing klinik, dan perawat pelaksana dalam kegiatan peserta praktik klinik keperawatan medikal bedah sangat menentukan keberhasilan kurikulum profesi ners. Untuk mewujudkan keberhasilan tersebut maka diperlukan standar kinerja sebagai penilaian penampilan kerja perawat dalam organisasi rumah sakit. Penilaian kinerja perawat merupakan proses yang berkelanjutan untuk menilai kualitas personal dan usaha untuk memperbaiki unjuk kerja perawat dalam sistim layanan kesehatan. Ada beberapa faktor yang mempengaruhi proses praktik keperawatan klinik, diantaranya adalah faktor klien, wahana praktik, perawat yang bertugas di tempat praktik, karakteristik praktikan. Keempat faktor tersebut saling mempengaruhi dan berdampak positif dalam peningkatan layanan kesehatan maupun pencapian tujuan belajar praktik klinik keperawatan (Nicklin \& Kenworthy, 2008). Salah satu masalah dalam kegiatan praktik klinik keperawatan medikal bedah adalah belum maksimalnya peran pembimbing klinik keparawatan dan kehadiran praktikan profesi ners masih dianggap sebagai tenaga tambahan. Berdasarkan hasil survey pada studi pendahuluan, diperoleh data bahwa hanya ada 4 perawat yang bertugas baik di ruang perawatan penyakit dalam, ruangan perawatan bedah, ruangan perawatan intensif, dan kamar bedah, yang sudah dibekali dengan pelatihan tentang konsep "Clinical Instructor". Keempat perawat tersebut mempunyai peran dan tanggung jawab baik sebagai kepala ruang perawatan maupun sebagai pembimbing klinik. Karena masing-masing mengemban dua tanggung jawab besar maka tingkat kesibukannya cukup tinggi sehingga memiliki keterbatasan waktu dalam proses bimbingan kepada mahasiswa praktikan. Hal tersebut berdampak pada penurunan pencapaian kompetensi klinik bagi para praktikan. Dilandasi masalah tersebut, maka perlu dilakukan suatu proses identifikasi melalui tahapan penelitian yang bertujuan untuk mencari hubungan kinerja perawat profesional dengan praktik klinik keperawatan medikal bedah mahasiswa profesi ners di RSUD Jayapura Provinsi Papua.

Tujuan dari penelitian ini adalah mengidentifikasi hubungan kinerja perawat profesional dengan praktik klinik keperawatan medikal bedah mahasiswa profesi ners di RSUD Jayapura Provinsi Papua. Hasil penelitian ini akan bermanfaat dalam penentuan standar kinerja pembimbing klinik yang dapat mengakomodasi pencapaian kompetensi klinik sesuai kurikulum berbasis kompetensi bagi para mahasiswa profesi ners.

\section{METODE PENELITIAN}

Penelitian ini menggunakan metode penelitian kuantitatif dengan pendekatan cross sectional studi. Selama proses penelitian, sebanyak 73 responden bersedia untuk berpartisipsi terdiri dari 7 kepala ruang perawatan, 8 pembimbing klinik, dan 58 perawat pelaksana. Adapun teknik sampling yang digunakan adalah total sampling. Selanjutnya terhadap responden praktikan yang dilibatkan sebagai responden silang sebanyak 49 mahasiswa profesi ners yang sedang melaksanakan praktik klinik keperawatan medikal bedah selama 3 bulan di RSUD Jayapura Provinsi Papua. Pengumpulan data dilakukan dengan cara survey dengan menggunakan kuesioner yang telah diuji coba dan dianalisa dengan menggunakan sistim komputerisasi. Variabel yang diteliti adalah kinerja perawat dalam proses bimbingan praktik klinik keperawatan medikal bedah pada mahasiswa profesi ners yang meliputi pelaksanaan tanggung jawab, ketaatan terhadap fungsi, tugas dan tanggung jawab, dan kerjasama. Data dianalisa secara deskriptif dengan hasil prosentase, kemudian dilakukan uji mean untuk masing-masing sub variabel kinerja baik kepala ruang perawatan, pembimbing klinik, dan perawat pelaksana.

\section{HASIL PENELITIAN}

berikut ini.

Hasil penelitian disajikan dalam tabel

Tabel 1 Kinerja Kepala Ruang Perawatan dalam Pelaksanaan Praktik Klinik Keperawatan Mahasiswa Profesi Ners di RSUD Jayapura, Juli 2014

\begin{tabular}{|c|c|c|c|c|}
\hline \multirow{3}{*}{$\begin{array}{c}\text { Kategori } \\
\text { Kinerja }\end{array}$} & \multicolumn{4}{|c|}{ Penilaian } \\
\hline & \multicolumn{2}{|c|}{ Kepala Ruang } & \multicolumn{2}{|c|}{$\begin{array}{l}\text { Mahasiswa } \\
\text { Profesi Ners }\end{array}$} \\
\hline & f & $\%$ & $\mathbf{f}$ & $\%$ \\
\hline $\begin{array}{l}\text { Kinerja } \\
\text { Rendah } \\
(1-1,750)\end{array}$ & 0 & 0 & 0 & 0 \\
\hline $\begin{array}{c}\text { Kinerja } \\
\text { Kurang } \\
(1,751-2,500)\end{array}$ & 0 & 0 & 6 & 12,3 \\
\hline $\begin{array}{c}\text { Kinerja } \\
\text { Cukup } \\
(2,501-3,250)\end{array}$ & 1 & 17,7 & 23 & 46,9 \\
\hline $\begin{array}{c}\text { Kinerja } \\
\text { Tinggi } \\
(3,251-4,000)\end{array}$ & 6 & 82,3 & 20 & 40,8 \\
\hline
\end{tabular}

Tabel 2 Kinerja Perawat Pelaksana dalam Pelaksanaan Praktik Klinik Keperawatan Mahasiswa Profesi Ners di RSUD Jayapura, Juli 2014 


\begin{tabular}{|c|c|c|c|c|}
\hline \multirow{3}{*}{$\begin{array}{c}\text { Kategori } \\
\text { Kinerja }\end{array}$} & \multicolumn{4}{|c|}{ Penilaian } \\
\hline & \multicolumn{2}{|c|}{$\begin{array}{l}\text { Perawat } \\
\text { Pelaksana }\end{array}$} & \multicolumn{2}{|c|}{$\begin{array}{l}\text { Mahasiswa } \\
\text { Profesi Ners }\end{array}$} \\
\hline & f & $\%$ & $\mathbf{f}$ & $\%$ \\
\hline $\begin{array}{c}\text { Kinerja } \\
\text { Rendah } \\
(1-1,750)\end{array}$ & 0 & 0 & 0 & 0 \\
\hline $\begin{array}{c}\text { Kinerja } \\
\text { Kurang } \\
(1,751-2,500)\end{array}$ & 3 & 5,2 & 11 & 22,5 \\
\hline $\begin{array}{c}\text { Kinerja } \\
\text { Cukup } \\
(2,501-3,250)\end{array}$ & 12 & 21,7 & 23 & 46,9 \\
\hline $\begin{array}{c}\text { Kinerja } \\
\text { Tinggi } \\
(3,251-4,000)\end{array}$ & 43 & 74,1 & 15 & 30,6 \\
\hline
\end{tabular}

Tabel 3 Kinerja Pembimbing Klinik dalam Pelaksanaan Praktik Klinik Keperawatan Mahasiswa Profesi Ners di RSUD Jayapura, Juli 2014

\begin{tabular}{|c|c|c|c|c|}
\hline \multirow{3}{*}{$\begin{array}{l}\text { Kategori } \\
\text { Kinerja }\end{array}$} & \multicolumn{4}{|c|}{ Penilaian } \\
\hline & \multicolumn{2}{|c|}{$\begin{array}{c}\text { Pembimbing } \\
\text { Klinik }\end{array}$} & \multicolumn{2}{|c|}{$\begin{array}{l}\text { Mahasiswa } \\
\text { Profesi Ners }\end{array}$} \\
\hline & $\mathbf{f}$ & $\%$ & $\mathbf{f}$ & $\%$ \\
\hline $\begin{array}{c}\text { Kinerja } \\
\text { Rendah } \\
(1-1,750)\end{array}$ & 0 & 0 & 0 & 0 \\
\hline $\begin{array}{c}\text { Kinerja } \\
\text { Kurang } \\
(1,751-2,500)\end{array}$ & 2 & 25,0 & 11 & 23,4 \\
\hline $\begin{array}{c}\text { Kinerja } \\
\text { Cukup } \\
(2,501-3,250)\end{array}$ & 4 & 50,0 & 21 & 42,9 \\
\hline $\begin{array}{c}\text { Kinerja } \\
\text { Tinggi } \\
(3,251-4,000)\end{array}$ & 2 & 25,0 & 17 & 34,7 \\
\hline
\end{tabular}

\section{PEMBAHASAN}

\section{Kinerja Kepala Ruang Perawatan}

Hasil penelitian ini menunjukkan bahwa terdapat perbedaan kategori kinerja kepala ruang perawatan dalam pelaksanaan bimbingan praktik klinik keperawatan medikal bedah berdasarkan penilaian sendiri kepala ruang perawatan dan penilaian dari mahasiswa profesi ners yang sedang melaksanakan kegiatan praktik keperawatan medikal bedah. Adapun kategori tersebut yaitu kinerja tinggi $82,3 \%$ responden berdasarkan penilain sendiri kepala ruang perawatan dan kinerja cukup $17,7 \%$ responden berdasarkan penilaian mahasiswa profesi ners (tabel 1). Dari perbedaan tersebut dapat disimpulkan kinerja kepala ruang perawatan belum maksimal dalam melakukan proses bimbingan klinik bagi mahasiswa profesi ners. Hal ini sesuai dengan penilaian mahasiswa profesi ners yang menerima perlakukan bimbingan klinik keperawatan. Setelah dilakukan uji mean, maka diketahui rerata kinerja kepala ruang perawatan menurut penilaian sendiri dalam pelaksanaan praktik klinik keperawatan medikal bedah dengan kategori tinggi meliputi pelaksanaan tanggung jawab (3,516), ketaatan terhadap fungsi, tugas, dan tanggung jawab $(3,462)$, dan kerjasama $(3,623)$. Sedangkan kinerja kepala ruang perawatan menurut mahasiswa profesi ners yang melaksanakan praktik keperawatan medikal bedah dengan kategori cukup yang meliputi pelaksanaan tanggung jawab $(3,256)$, ketaatan terhadap fungsi, tugas, dan tanggung jawab $(3,146)$, dan kerjasama $(3,221)$ (tabel 2). Hasil uji mean menunjukkan bahwa tanggung jawab kepala ruang perawatan juga belum maksimal. Hal ini disebabkan oleh karena adanya perangkapan jabatan oleh kepala ruang perawatan baik sebagai kepala ruang perawatan maupun sebagai pembimbing klinik keperawatan sehingga tidak ada kesesuaian antara kemampuan dan beban kerja yang bersifat rutinitas. Setiap kepala ruang perawatan memiliki kapasitas untuk menyelesaikan berbagai tugas dalam pekerjaan yang meliputi kemampuan intelektual, fisik dan sikap profesional. Jika ada kesesuai antara kemampuan dan jenis pekerjaan yang dilakukan oleh kepala ruang perawatan, maka secara langsung akan memotivasi peningkatan prestasi kerja staf perawatan (Clarke, 2004).

\section{Kinerja Perawat Pelaksana}

Hasil penelitian ini menunjukkan bahwa terdapat perbedaan kategori kinerja perawat pelaksana dalam pelaksanaan bimbingan praktik klinik keperawatan medikal bedah berdasarkan penilaian sendiri perawat pelaksana dan penilaian dari mahasiswa profesi ners yang sedang melaksanakan kegiatan praktik keperawatan medikal bedah. Adapun kategori tersebut yaitu kinerja tinggi $74,1 \%$ responden berdasarkan penilain sendiri perawat dan kinerja cukup 46,9\% responden berdasarkan penilaian mahasiswa profesi ners (tabel 3). Hasil uji mean menunjukkan bahwa tanggung jawab perawat pelaksana juga belum maksimal. Hal ini disebabkan kurangnya penjelasan akan uraian prosedural kegiatan praktik bagi mahasiswa, sehingga secara keseluruhan para perawat pelaksana yang ada menganggap bahwa mahasiswa yang sedang berpraktik pada institusi layanan kesehatan adalah sebagai tenaga tambahan yang meringankan beban kerja bagi perawat pelaksana. Perawat pelaksana cenderung menyerahkan sebagian tanggung jawabnya kepada 
mahasiswa yang sedang praktik. Kebiasaan ini menjadi turun-temurun setiap ada mahasiswa yang sedang praktik, dan dapat diprediksi bahwa hal tersebut bisa menimbulkan arogansi seorang peserta didik yang berdampak pada kejadian malpraktik.

\section{Kinerja Pembimbing klinik}

Hasil penelitian ini menunjukkan bahwa terdapat perbedaan kategori kinerja pembimbing klinik dalam pelaksanaan bimbingan praktik klinik keperawatan medikal bedah berdasarkan penilaian sendiri pembimbing klinik dan penilaian dari mahasiswa profesi ners yang sedang melaksanakan kegiatan praktik keperawatan medikal bedah. Adapun kategori tersebut yaitu kinerja cukup 50\% responden berdasarkan penilain sendiri perawat dan kinerja cukup $42,9 \%$ responden berdasarkan penilaian mahasiswa profesi ners (tabel 3). Hasil uji mean menunjukkan bahwa tanggung jawab pembimbing klinik juga belum maksimal. Hal ini disebabkan oleh karena masih banyak pembimbing klinik yang belum mengikuti pelatihan bimbingan klinik. Hanya ada 2 orang dari 8 orang pembimbing klinik yang sudah dibekali dengan pendidikan non formal yaitu pelatihan clinical instructur. Hal ini berdampak pada kurangnya pemahaman akan konsep bimbingan bagi pembimbing klinik, kurangnya motivasi bimbingan pada mahasiswa yang sedang melaksanakan kegiatan praktik, dan output dari peserta didik dalam melaksanakan peran dan tanggung jawabnya tidak optimal. Secara konsep seorang pembimbing klinik dituntut tidak hanya membantu para praktikan dalam menggunakan konsep dan teori yang berhubungan dengan praktik dan pengembangan keterampilan klinik keperawatan, namun juga harus dapat memotivasi para praktikan dalam menerima berbagai sudut pandang, tantangan dan pertanyaan dan mengembangkan komitmen sebagai praktikan klinik yang bertanggung jawab dan bertanggung gugat. Seorang pembimbing klinik juga perlu memperlihatkan perilaku profesional dalam melaksanakan tugas dan tanggung jawabnya. Perilaku profesional tersebut tercermin pada peningkatan keinginan belajar mahasiswa, peningkatan iklim belajar yang kondusif, peningkatan rasa percaya diri bagi mahasiswa, hubungan personal yang bersifat profesional diantara sejawat perawatan dan mahasiswa bahkan klien dan keluarganya. Pembimbing klnik bertanggung jawab dan bertanggung gugat untuk memberikan pengalaman belajar klinis bagi mahasiswa praktik klinik keperawatan.

Kemampuan kerja adalah kapasitas individu dalam menyelesaikan berbagai tugas dan tanggung jawabnya dalam pekerjaan yang meliputi kemampuan intelektual, keterampilan, dan sikap.
Prestasi kerja akan meningkat jika ada kesesuaian antara kemampuan dan jenis pekerjaan (Yasmin, 2004). Analisis jabatan merupakan hal yang mendasari proses pengembangan sumber daya manusia dengan mencocokkan karakteristik individu baik pengetahuan, keterampilan, dan pengalaman. Jika tidak ada standar kriteria dalam penentuan pembimbing klinik, maka akan berdampak pada manajemen kinerja pembimbing klinik.

\section{SIMPULAN DAN SARAN Simpulan}

Banyak faktor yang turut mempengaruhi pelaksanaan praktik klinik keperawatan. Yang paling utama adalah kinerja dari tiap unsur yang terkait dalam kegiatan tersebut. Dalam penelitian ini terdapat 4 unsur penting yang saling berhubungan erat dalam pelaksanaan praktik klinik keperawatan, yaitu kinerja kepala ruang perawatan, kinerja perawat pelaksana, kinerja pembimbing klinik keperawatan, dan antusias dari para mahasiswa sebagai peserta praktik klinik keperawatan. Hasil penelitian ini menyatakan bahwa belum maksimalnya kinerja baik kepala ruang perawatan, perawat pelaksana, dan pembimbing klinik keperawatan dalam memfasilitasi para mahasiswa profesi ners dalam pelaksanaan praktik klinik keperawatan medikal bedah. Hal ini akan berdampak pada pencapaian target kompetensi klinik keperawatan bagi mahasiswa yang sedang melaksanakan praktik keperawatan. Pihak manajemen bidang keperawatan dan kepala diklat institusi rumah sakit beserta pihak institusi pendidikan tinggi keperawatan, hendaknya saling berkoordinasi terkait kinerja dan pencapaian target kompetensi bagi para mahasiswa keperawatan yang sedang melaksanakan praktik keperawatan klinik pada institusi pelayanan kesehatan. Perlunya pengembangan keilmuan dan keterampilan klinik keperawatan melalui pendidikan non formal yaitu pelatihan pembimbing klinik bagi para perawat yang akan ditunjuk sebagai pembimbing klinik perawatan.

\section{Saran}

Pihak manajemen bidang keperawatan dan kepala diklat institusi rumah sakit beserta pihak institusi pendidikan tinggi keperawatan,hendaknya mempertimbangkan beberapa hal berikut yaitu saling berkoordinasi terkait kinerja dan pencapaian target kompetensi bagi para mahasiswa keperawatan yang sedang melaksanakan praktik keperawatan klinik pada institusi pelayanan kesehatan, perlunya pengembangan keilmuan dan keterampilan klinik keperawatan melalui pendidikan non formal yaitu pelatihan pembimbing 
klinik bagi para perawat yang akan ditunjuk sebagai pembimbing klinik perawatan, perlunya penunjukan seorang pembimbing klinik dengan kualifikasi pendidikan ners yang dapat dijadikan panutan/model, dan mengintensifkan peran pembimbing klinik dari institusi pendidikan untuk terlibat langsung dan senantiasa berkoordinasi dengan pihak wahana praktik.

\section{DAFTAR RUJUKAN}

Billings \& Halstead. (2005). Teaching in Nursing Professional: A Guide for Faculty. St. Louis Missouri. Elsevier Saunders.

Dorothy. (2002). Pengajaran Klinis Dalam Pendidikan Keperawatan. EGC. Jakarta. Djoerban, Z. (2011).

Nicklin \& Kenworthy. (2008). Teaching and Assesing in Nursing Practice. London: Scutari Press.

Notoadmodjo, S. (2003). Pengantar Ilmu Kesehatan dan Ilmu Perilaku. Andi Offset. Yogyakarta.

Yasmin, T. (2004). Kinerja Manajemen SDM. Penerbit FEUI 